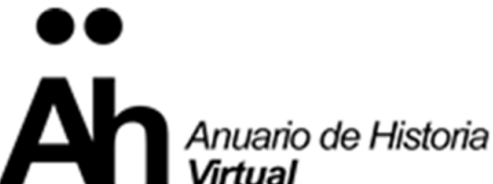

\section{La moral en la interpretación del pasado en la historiografía latina}

\author{
[Morality in the Interpretation of the Past in Latin Historiography]
}

\author{
Agustín Moreno \\ (Universidad Nacional de Córdoba - CIECS) \\ agustimoreno2003@yahoo.com.ar
}

\begin{abstract}
Resumen
Este artículo reflexiona sobre algunos aspectos centrales de la historiografía latina que han sido foco del debate en las últimas décadas. En la primera parte, presenta un estado de la cuestión sobre el tema de la veracidad y el peso de la retórica en las narraciones de los historiadores. En la segunda parte, analiza el rol de la moral en la interpretación de los hechos que ofrecen dichas narraciones.
\end{abstract}

Palabras claves: Historiografía latina Veracidad - Retórica - Auctoritas - Moral

\begin{abstract}
This paper deals with some main aspects of Latin historiography that have been discussed in the last past decades. In the first part, it presents a state of the art on the subject of veracity and the importance of rhetoric in the historians' narratives. In the second part, it analyzes the role of morality in the interpretation of the facts that those narratives present.
\end{abstract}

Keywords: Latin Historiography - Veracity Rhetoric - Auctoritas - Morality

Recibido: 16/09/2016

Evaluación: 16/10/2016

Aceptado: 20/11/2018

Anuario de la Escuela de Historia Virtual - Año 9 - No 14 - 2018: pp. 5-25.

ISSN: 1853-7049

http://revistas.unc.edu.ar/index.php/anuariohistoria 
6 I La moral en la interpretación del pasado en la historiografía latina

\section{La moral en la interpretación del pasado en la historiografía latina}

“... we cannot assess the truth-claims of ancient historians until we understand better what it is that they were attempting to do in their narratives of the past. Only by examining them on their own terms can we begin to approach an understanding of how they saw their task". (Marincola, 2006, p. 8).

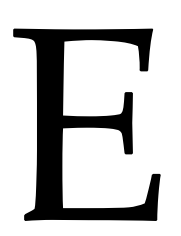

$\mathrm{n}$ las últimas décadas, a partir del debate que enfrentó principalmente a $\mathrm{T}$. P. Wiseman y A. J. Woodman con T. J. Cornell en los' 80 se ha generado una extensa bibliografía que ha profundizado en diferentes aspectos de la historiografía grecolatina, algunos ya sobre la mesa al momento del inicio de la discusión, otros que vieron la luz como fruto de la misma. ${ }^{1}$ Las explicaciones que fueron surgiendo han apuntado, como se advierte en la frase de J. Marincola de nuestro epígrafe, a romper con los preconceptos que los investigadores arrastramos en nuestras lecturas de las fuentes. En este marco de reflexión, cobra relevancia considerar la escritura de la historia no como una práctica aislada de las demás que se desarrollan en una sociedad, sino teniendo en cuenta otros aspectos de la cultura desde la que se busca interpretar el pasado y las funciones que tiene el conocimiento de la historia en dicha sociedad.

En ese sentido, profundizar en el estudio del modo en que los romanos concebían el mundo, es decir, daban sentido a la realidad que los rodeaba, nos ayuda a comprender más sobre su manera de escribir historia. Esto es así, puesto que el discurso histórico refleja esa forma de entender el mundo, de allí que los exempla positivos que aparecen a

\footnotetext{
${ }^{1}$ Este debate continúa aquel que había comenzado A. Momigliano con H. White, ver: Marincola (2006, pp. 3-5). Esto se ve claramente en la crítica que Cornell hace directamente al investigador norteamericano en Los orígenes de Roma c. 1000-264 a.C. Italia y Roma de la Edad del Bronce a las guerras púnicas (1999, pp. 35-36, $461 \mathrm{n}$. 40). Momigliano es uno de los primeros historiadores en reaccionar contra la tesis de White en "Historicism Revisited", publicado al año siguiente de la aparición de Metahistoria. Ver también: Momigliano (1992, pp. 16-20). Su postura es retomada por C. Ginzburg en "Unus Testis" y "Apéndice. Pruebas y posibilidades", ambos textos reeditados en su libro El hilo y las huellas. Ver, asimismo: Serna y Pons (2005, pp. 173-206), en donde se resumen no solo las posturas de White y Momigliano, sino también las intervenciones de otros investigadores en el debate entre historiadores culturales y sus pares posmodernos del giro lingüístico. Para un balance crítico interesante de la postura de White dentro de la historiografía contemporánea, ver: Cabrera (2005). Entre los textos más influyentes de White entre los estudiosos de la historiografía grecolatina podemos citar la introducción a su Metahistoria y el capítulo "el valor de la narrativa en la representación de la realidad" en El contenido de la forma. Narrativa, discurso y representación histórica. Algunos de los argumentos expuestos en la primera fueron retomados en su ensayo "El texto histórico como artefacto literario", en el que también se pueden observar ideas que desarrolló en el segundo.
}

Anuario de la Escuela de Historia Virtual - Año 9 - N 14 - 2018: pp. 5-25. ISSN: 1853-7049 
lo largo de una obra puedan ser asimilados e imitados y los exempla negativos puedan ser reconocidos para así evitarlos.

Considerando estas cuestiones, el presente artículo presenta, en un primer momento, un repaso crítico de algunos aspectos centrales de la historiografía latina que han sido foco del debate sobre la cuestión de la veracidad y la importancia de la retórica en las narraciones históricas latinas. En un segundo momento, retomando algunos puntos de ese debate, se pretende sugerir un modo diferente de entender la cuestión prestando mayor atención al lugar de la moral en la cultura romana.

\section{¿Veracidad, verosimilitud o invención? Un estado de la cuestión}

Como no podía ser de otra manera, uno de los puntos que más polémica ha generado en el debate es el tema de la veracidad, pues es aquello que diferencia al género historiográfico de otros géneros que también tratan sobre el pasado. Dicha cuestión es relevante para los investigadores modernos tanto por el contexto de producción de las obras como por los datos que podemos tomar de ellas para nuestra reconstrucción del pasado sobre el que dichas obras nos informan: ¿En qué medida podemos fiarnos de lo que nos dicen las fuentes? ¿En qué medida hemos de creer en sus declaraciones de que no se apartarán de la verdad que los historiadores aducen al comienzo de sus obras? ¿Acaso debemos leer sus obras como una narración ficcional? ¿Nuestra concepción historiográfica es aplicable al estudiar la práctica latina? ¿Debemos emplear nuestras nociones para juzgar el valor de las obras romanas?

Estos interrogantes, frutos en varios casos de preconceptos no cuestionados, por lo general, están asociados a juicios de valor sobre los autores. Entre los historiadores romanos, dentro de los cuales se destacan en distintos períodos Salustio, Tito Livio y Tácito, el segundo es quien ha sido víctima de los juicios más negativos. Ha sido conceptuado por diferentes investigadores como un historiador poco original que se dedicaba a hacer un collage de lo que encontraba en sus fuentes; no sabía de geografía, ${ }^{2}$ ni de política, ${ }^{3}$ ni de nada en lo atinente a las prácticas militares; ${ }^{4}$ era escéptico en religión o

\footnotetext{
${ }^{2}$ Ej.: Walsh (1963, pp. 4, 273) y Ogilvie (1970, p. 1). De todos modos, la acusación sobre falta de interés por la geografía es una acusación que se ha hecho en general a los historiadores romanos: sobre Tácito, véase: Syme (1997, pp. 126-127); sobre Salustio, ver: Syme (1982, p. 129) y Paul (1984, pp. 2, 5-6, 70-71); sobre Amiano Marcelino, ver: Sundwall (1996); Drijvers (1998) y López Ramos (2008).

${ }^{3}$ Ej.: Syme (1997, p. 139) y Walsh (1963, p. 273).

${ }^{4}$ Ej.: Syme (1997, p. 139); Walsh (1963, pp. 4, 273); Ogilvie (1970, p. 2) y Luce (1977, pp. 39-41, 216-217). Tácito también sufrió, ya hace tiempo, críticas al respecto de sus narraciones militares, como podemos leer en el discurso inaugural de la Society for the Promotion of Roman Studies pronunciado por Haverfield (1911, p. xii): "Tacitus, I am inclined to believe, got his modern soubriquet of the "most unmilitary of historians" not from any particular indifference to military history, but because he refused to load his paragraphs with any sort of technical minutiae, whether of tactics and strategy, and of anything else. He preferred the emotional and ethical aspects of war, as of other things, and he eschewed the scientific description of marches or maoenuvres (sic $=$ manoeuvres) just as he omitted all scientific or technical detail". Allí, advertimos que tanto aquellos que son foco de la crítica del historiador inglés como él mismo estarían leyendo a Tácito
} 
8 | La moral en la interpretación del pasado en la historiografía latina

un protestante avant la lettre, ${ }^{5}$ tenía dificultades con el griego, ${ }^{6}$ etc. En ese marco, la escuela de la Quellenforschung intentó, principalmente, detectar las fuentes que estaban detrás de diferentes episodios ofrecidos por Tito Livio para atribuirles las opiniones que se encontraban en la obra. Trabajo difícil y que sin duda dejó sus aportes, pero que también llevó a valorar más a escritores cuyas obras no nos han llegado que a aquellos, como Tito Livio, de cuyo trabajo sí disponemos. ${ }^{7}$

Todas estas afirmaciones han llevado, creemos, a resultados sesgados de la obra y del autor. Tal vez, en cuanto a la verdad, una de las tesis que resume el modo anacrónico con que se leía -y algunos aún leen- la obra de Tito Livio es la de P. G. Walsh: "He has falsified history not by error but by design", pues, Tito Livio en su afán de construir lecciones morales habría distorsionado los hechos. ${ }^{8}$ Pero, deberíamos preguntarnos, cuando acusamos a Tito Livio (o a otro historiador latino) de falsificar la historia: ¿en qué forma de concebir la práctica historiográfica estamos pensando? Y fundamentalmente: ¿en qué modo de interpretar los hechos?

En ese sentido, los aportes de la aproximación literaria encabezada por T. P. Wiseman y A. J. Woodman ayudaron a corregir algunas apreciaciones de los investigadores de la Quellenforschung poniendo énfasis en el elemento retórico, en ocasiones excesivo énfasis. Esta aproximación ha puesto en tela de juicio el grado de confiabilidad que las fuentes latinas tienen para el investigador actual. Así, Wiseman afirmó que los autores grecorromanos pensaban que lo único que podía apartar de la verdad era la parcialidad política. Sin embargo, ese criterio de verdad no limitaba a los autores al momento de tratar temas mitológicos. Aquellos racionalizaban el mito y, como al relatar los hechos sobre un personaje no había motivos para mentir, se los empleaba para contar verosimilitudes. Esto, para Wiseman, pone en evidencia que el índice de precisión histórica era limitado. ${ }^{9}$

anacrónicamente. Un balance de la información militar en la Historias de Tácito con discusión de opiniones modernas al respecto ofrece Syme (1997, pp. 157-175). Ver, asimismo: Moralejo (2002, p. 13).

${ }^{5}$ Así rotula Linderski (1993, p. 54) la interpretación de Walsh sobre la postura religiosa de Tito Livio.

${ }^{6}$ Han defendido esta tesis de la dificultad de Tito Livio con el griego entre otros Walsh (1958; 1963, pp. 143144); Ogilvie (1970, pp. 1, 7) y Briscoe (1973, p. 6). Para los pasajes en que la versión de Tito Livio no se correspondería con la de su fuente Polibio ver los comentarios de Briscoe, quien parece mantener su posición de 1973 en sus trabajos posteriores, Briscoe (2003; 2008; 2012). Entre aquellos que sostienen que Tito Livio sí manejaba bien el griego y proponen soluciones diferentes a los pasajes problemáticos, podemos citar a De Foucault (1968); Luce (1977, pp. 169-170) y Fontán (1984).

${ }^{7}$ Sobre las críticas a la Quellenforschung, ver: Bayet (1958, pp. XXVI y ss.); Goodyear (1966, p. 62); Briscoe (1973, pp. 1-12); Luce (1977, pp. XV-XXVI y passim); Cornell (1999, pp. 21, 23-4; 2005, pp. 49, 62, 64); Jaeger (1997, p. 8); Oakley (2004, pp. 16-18) y Miles (1997, pp. 1-7).

${ }^{8}$ La cita está en Walsh (1963, p. 109). La idea es estudiada por Walsh en varias ocasiones: Walsh (1955; 1963, pp. 82-109; 1982). Una idea similar a la aludida arriba de Walsh leemos sobre Tácito en Moralejo (2002, p. 20). Para críticas a la falta de cientificidad en el Agrícola de Tácito consultar las opiniones de Marín Peña citadas por Requejo (1981, pp. 44 y 51).

${ }^{9}$ Wiseman (1987, pp. 256-7 y 259). Wiseman considera que la defensa sobre la verdad de los historiadores antiguos que hace Brunt (1979) no es convincente, ni la separación que plantea entre historia y oratoria. Wiseman atribuye un 'unhistorical thinking' a los historiadores romanos, quienes componen discursos para sus personajes con poco o ningún conocimiento del discurso pronunciado originalmente, por incluir elementos posibles, pero inventados en sus narrativas. De este modo, Wiseman considera que la manera en que desplegaban la inventio los analistas de la República tardía podía ser entendida en nuestros términos

Anuario de la Escuela de Historia Virtual - Año 9 - N 14 - 2018: pp. 5-25. ISSN: 1853-7049 
Poco después, en 1988, Woodman profundizó esa tesis. Para este investigador, los romanos entendían la verdad en términos de imparcialidad y no, por consiguiente, como lo entiende la concepción historiográfica tradicional, según patrones modernos, como un opuesto a la ficción. ${ }^{10}$ Esto lo vincula con la inventio, por medio de la cual se elaboraba un material y que, en las obras históricas, terminaba por otorgar un mismo estatus a la verdad y a lo probable. ${ }^{11}$ En esa instancia, se advierte una similitud entre la práctica del orator y la del historiador, pues este, como el abogado, debe construir una interpretación del pasado que sea probable y que conmueva y convenza a la audiencia. ${ }^{12}$

Pero la pregunta que se hace Woodman es cómo pueden los autores en ocasiones señalar que la historia ha sido tergiversada si la escritura de la historia depende de esa inventio retórica. Él sostiene:

"The explanation of the paradox would seem to be that the Romans required the hard core of history to be true and its elaboration to be plausible, and further that they saw no contradiction between these two requirements but rather regarded them as complementary". ${ }^{13}$

E incluso, afirma Woodman sobre esta cuestión, que la veracidad de este núcleo duro era un tema sumamente importante, pues, es lo que distingue a la historia de otras ramas de la literatura. ${ }^{14}$ Sin embargo, la distinción entre esos datos que hacen al núcleo duro

como mera invención, lo que se advierte, según Wiseman, en la extensión que los historiadores como Tito Livio le han dedicado posteriormente a los períodos relatados más brevemente por los analistas y repercute en la escasa confiabilidad de la evidencia para la historia de Roma temprana. Véase Wiseman (1987, pp. 246247, 251, 257-258).

${ }^{10}$ Woodman (2004, pp. 74, 82-83, 87, 102 n. 12). Vemos aquí y en lo que sigue cómo Woodman retoma las tesis de White, el "inductor del giro lingüístico"... e "inspirador de la posmodernidad en la disciplina" histórica (Serna y Pons, 2005, p. 189), y las aplica directamente a la práctica grecolatina. El tema de las causas que pueden conducir a la acusación de parcialidad contra el historiador en la práctica grecolatina ha sido estudiado con más detenimiento por Luce (1989).

${ }^{11}$ En la Retórica a Herenio encontramos la siguiente definición de inventio: "inventio est excogitatio rerum verarum aut veri similium, quae causam probabilem reddant" (Her. I.2.3). Ver también: Cic. Inv. I.9.

12 Woodman (2004, pp. 87-88). Woodman piensa, principalmente, en Cic. de Orat. II.62-64. Sobre este punto, afirma Wiseman: "It is important to remember that Cicero is speaking through the mouth of M. Antonius that is, one master-orator impersonating another. And he has a case to make, that history is part of the universal range of the orator's competence. We need not expect the neutral exposition of objective data, but the marshalling of arguments to prove a point". (Wiseman, 1999, p. 3). Ver, asimismo, Nicolai (2007, pp. 2122) y Damon (2007, pp. 440-443).

${ }^{13}$ Woodman (2004, p. 91). Y agrega: "Thus if a historian had reason to believe that his hard core was false, it seems that he was debarred from using it for the purposes of exaedificatio. If, on the other hand, an historian was faced with an awkward but true hard core, he was under an obligation not to omit it: on the contrary, he should employ all his rhetorical skill to put a good interpretation upon it. Such a challenge was indeed the very essence of rhetoric". (Woodman, 2004, pp. 91-92).

${ }^{14}$ Woodman (2004, p. 92). En 1993, Wiseman manteniéndose en esta postura de la escasa fiabilidad de las fuentes históricas, profundiza en los límites al momento de narrar la historia y se detiene en siete aspectos por los que un historiador podía ser criticado por mentir: tendenciosidad -la falta de imparcialidad de la que habla Woodman (2004)-, contar mûthoi (mitos, fábulas), cuentos de viajeros, efectos retóricos y dramáticos que afectan la práctica de escribir historia, cuando en una obra la aphêêesis (narración) es más importante que la historia, cuando se elabora el material (inventio) en exceso dando demasiados detalles y su opuesto, cuando no se ofrecen demasiados detalles, cuando no hay elaboración. Para una crítica al artículo de Wiseman, ver: Bosworth (2003, pp. 169-170).

Anuario de la Escuela de Historia Virtual - Año 9 - N 14 - 2018: pp. 5-25. ISSN: 1853-7049 
(monumenta) y la superestructura (ornamenta) que en la teoría existía, en la práctica no era con frecuencia posible de distinguir. ${ }^{15}$

Contra esta aproximación y, fundamentalmente, contra las tesis defendidas por Wiseman reacciona el discípulo de A. Momigliano, T. J. Cornell, en su reseña a Clio's Cosmetics. Cornell acepta el empleo de la retórica por parte de los historiadores, no obstante, precisa que la cuestión radica en determinar en qué medida aquella afecta a la información proporcionada en las obras. Cornell insiste en que para Cicerón la principal tarea del historiador era decir la verdad y que ello debía hacerse de un modo que fuera convincente y agradable para el lector. ${ }^{16}$ Luego, en cuanto a las similitudes entre historia y poesía propuestas por Wiseman, afirma que, si bien el tema sobre el que trataban historiadores y poetas pudo ser el mismo, esto no implica que no se reconociera una distinción entre los dos géneros. Y en lo atinente a los hechos relatados, Cornell enfatiza que los antiguos sí distinguían entre los hechos históricos y los míticos, aunque admite que algunos autores pudieron haber sido más conscientes que otros. ${ }^{17}$

Sin embargo, para Cornell, la principal falencia del planteo de Wiseman reside en la sobredimensión de la cantidad de material inventado que pudieron haber introducido los analistas de la República tardía en sus obras. Esto se debe a diferentes aspectos: primero, estos analistas escribían sobre temas que ya hacía un siglo venían siendo tratados y los lineamientos de la narración tradicional reposaban no solo en los Fastos, sino también en obras de personajes importantes con la suficiente auctoritas como para que llamara la atención una divergencia notoria en la narración de los acontecimientos. ${ }^{18}$ Segundo, la tradición histórica romana tenía importancia para la clase gobernante en general porque era un tema de implicancia política y, por ello, estaba presente entre sus miembros. ${ }^{19}$ De este modo, las ocasiones en que un analista podía inventar y ser creído eran muy acotadas. En cambio, basándose en sendos pasajes del Bruto de Cicerón y de la Historia Romana de Tito Livio, ${ }^{20}$ Cornell afirma que la tergiversación de hechos que se advierte en la tradición puede haber sido fruto de enfrentamientos políticos de la vida

\footnotetext{
${ }^{15}$ Woodman (2004, pp. 92-93). Las recepciones del libro de Woodman no fueron todas tan acogedoras como la reseña de Wiseman (1988). Ver la crítica virulenta de Frier (1990), quien denuncia que Woodman no comprende lo que era la inventio retórica y asevera: "The historian builds on facts; he does not adorn a 'hard core' of fact with an 'elaboration' of 'plausible' fiction". (Frier, 1990, p. 462). Ver asimismo: Bosworth (2003, p. 168 n. 4$)$.

${ }^{16}$ Cornell (1982, p. 204).

${ }^{17}$ Cornell (1982, p. 204).

${ }^{18}$ En un trabajo posterior, Cornell afirma: “... the fact that the surviving accounts of Cicero, Diodorus, Dionysius, and Livy agree closely with one another on all fundamental points (and often in matters of fine detail) can only mean that there was a basic common tradition that is reflected in all of them. This received tradition must have been more or less faithfully reproduced in the works of earlier annalists, whose individual contributions were therefore effectively negligible". (Cornell, 2005, p. 52).

${ }^{19}$ Así, asevera Cornell: "The Roman historical tradition can be defined as the sum of what successive generations of Roman citizens believed about their own past". (Cornell, 1982, p. 206; 2005, p. 50). Y agrega: "The historical tradition of the Roman Republic was neither an authenticated official record nor an objective critical reconstruction, but rather an ideological construct, designed to control, to justify, and to inspire." (Cornell, 2005, p. 50). Ver también: Marincola (2009, p. 22).

${ }^{20}$ Cic. Br. 62, Liv. VIII.40.
}

Anuario de la Escuela de Historia Virtual - Año 9 - No 14 - 2018: pp. 5-25. ISSN: 1853-7049 
real y no ser producto de los analistas. ${ }^{21}$ De todos modos, sí se puede pensar en otras formas en que los analistas pudieron extender el material disponible en sus obras: con el uso del lenguaje, seleccionando u omitiendo información, presentando los episodios en un modo particular, asignando motivos, componiendo discursos para los personajes, etc. Estos aspectos eran reconocidos por Wiseman, aunque su énfasis en la invención de material sería exagerado más allá de estos puntos. ${ }^{22}$ Finalmente, en el addendum de su artículo "The Value of the Literary Tradition Concerning Archaic Rome", Cornell denuncia uno de los errores de la aproximación literaria: esta es en esencia anti-histórica, pues, en su análisis los investigadores que adscriben a la misma separan los textos de los acontecimientos que relatan; los historiadores son considerados como personalidades independientes, representantes de su tiempo y cultura y parte del mundo literario, pero paradójicamente no como historiadores. ${ }^{23}$

En 1993, J. Moles, basándose en un análisis de los prefacios de Heródoto y de Tucídides, hace una crítica a la postura defendida por Cornell -entre otros- sobre la posibilidad de separar la verdad fáctica de una superestructura retórica y sostiene, en cambio, que ambas partes están entrelazadas y que no es tan simple la operación que debe hacer el investigador moderno para determinar qué parte de la narración corresponde a los hechos sólidos y cuál es mera retórica. ${ }^{24}$ Inclusive, Moles va más allá en sus planteos. Señala que los historiadores grecorromanos en ocasiones relataban

${ }^{21}$ Así, leemos en su artículo publicado en Social Struggles in Archaic Rome: “The functional role of historical tradition in the political and social life of the Republic meant that the generally accepted picture of Rome's history was subject to a process of continuous transformation as each generation reconstructed the past in its own image. The successive reappraisals were registered in the works of the annalists, whose accounts naturally reflected contemporary preoccupations. They were not the creators of the historical tradition, but rather its purveyors". (Cornell, 2005, p. 50). Ver también: Cornell (2005, pp. 52 y 59), donde aclara: “The Romans' approach to their own early history was uncritical because it was not founded on the basic principle of historical criticism, which is that the past is different from the present. The preservation and transmission of traditional stories of the city's past should in no sense be seen as an attempt to understand the archaic period as it really was. Rather, the Romans of the late Republic saw the remote past as an idealised and exemplary model of their own society. They seem to have been almost totally unaware of the gulf that separated them from the archaic world of the fifth century B.C... The chief consequence of this unhistorical approach to the past was that the tradition was constantly subjected to a largely unconscious process of systematic anachronism". Ver, asimismo: Cornell (2005, pp. 60-62). Sobre la idea de la última cita consultar también: Roller (2004, p. 38).

${ }^{22}$ Cornell (1982, p. 206; 1999, pp. 34-36, 42, 48-50; 2005, pp. 48, 50, 58-60).

${ }^{23}$ Ibíd., p. 62. Ver, igualmente: Frier (1990). La misma posición crítica hacia la aproximación literaria es sostenida por Lendon (2009), quien reproduce las críticas de Cornell y añade otras. La afirmación que tomamos del addendum de Cornell, ya había sido enfatizada en 1984 por Momigliano (Serna y Pons, 2005, p. 196).

24 "Can the literary aspect of ancient historiography be sliced off like icing from Christmas cake? Emphatically, no. You can try to extract factual material from an ancient historiographical text, but (to change the metaphor) it is like cutting a vital organ from the body. You may or may not succeed (that depends on your surgical skill and the constitution of the individual body), but it will always be a messy business: you may take out more than you bargained for, and you cannot always be sure even which organ you should be pulling out. That is not to say that such surgery is unnecessary: modern historians are bound to try to abstract factual data from ancient historiographical texts, their main source of evidence, however recalcitrant; and for their part modern literary critics cannot properly gauge the originality and creativity of those texts without trying to establish the raw material upon which they are based". (Moles, 1993, pp. 114115).

Anuario de la Escuela de Historia Virtual - Año 9 - No 14 - 2018: pp. 5-25. ISSN: 1853-7049 
hechos que sabían que no eran fácticamente verdaderos. ${ }^{25} \mathrm{~A}$ partir de allí, Moles se pregunta si es posible establecer una teoría que nos permita entender la cuestión de la verdad en las fuentes antiguas sin recurrir a nuestra concepción moderna de la misma y sin calificar como mentirosos a los relatos en que a nuestros ojos los historiadores grecolatinos falsean los acontecimientos. A continuación, observa dos aspectos que la teoría formulada por Woodman no contempla: aquellos casos en que los historiadores afirman que es verdad lo que saben que no lo es y los casos en que la verdad no se entiende en términos de imparcialidad, sino de sólidos criterios históricos. ${ }^{26}$ Asimismo, Moles subraya que, más allá de la teoría, en la práctica existieron diferentes tipos de historiadores y si bien algunos prestaban atención a la verdad fáctica, otros empleaban herramientas retóricas e, incluso, otros realizaban sus narraciones con el único objetivo de entretener. ${ }^{27}$ Igualmente, más allá de estas diferenciaciones, los distintos tipos de historiadores compartían características, si bien las mismas se aprecian en las obras en diferente grado. Finalmente, retornando a la cuestión de que los autores afirmaran como verdadero algo que sabían o, al menos, sospechaban que no lo era, Moles subraya que hasta los historiadores más serios en ocasiones debían manipular la verdad fáctica en su narración para que sus enseñanzas morales quedaran bien configuradas. ${ }^{28}$

Una explicación diferente encontramos en un texto de C. Damon de 2007 publicado en A Companion to Roman Rhetoric. La autora analiza cuán confiables eran las narrativas históricas grecorromanas como fuentes históricas concentrándose en la cuestión de la inventio. ${ }^{29}$ Fundamentalmente, le interesa estudiar cuán lejos de la verdad se encuentra lo verosímil e, inherente a este punto, si sabremos cuándo comenzamos a ser conducidos hacia el terreno de lo verosímil. ${ }^{30}$

A nivel teórico, Damon señala que en la inventio está implícita la cuestión de que el contenido de la narración también contribuye a dar verosimilitud a la construcción que se hace del pasado. ${ }^{31} \mathrm{Y}$ tal como ya se ha venido subrayando en las últimas décadas el método histórico es asimilable a la práctica del orador forense y, en lo que atañe al tema de la invención de material, tiene límites similares. En el caso de los historiadores que se ocupen de acontecimientos contemporáneos podían sufrir refutación por parte de aquellos que participaron de dichos hechos. La auctoritas de los participantes de los acontecimientos relatados resultaba un constreñimiento importante para el historiador que,

${ }^{25}$ Moles (1993, p. 115).

${ }^{26}$ Moles (1993, p. 118).

${ }^{27}$ Moles (1993, p. 118).

${ }^{28}$ Moles (1993, pp. 120-121).

${ }^{29}$ Sobre este punto, Damon (2007, p. 440) aclara: “... I distinguish between inventio, which involves the discovery of true as well as truth-like material, and fiction or invention, which lacks evidentiary warrant". ${ }^{30}$ Para ello, los discursos son útiles, pues, si bien se acepta que eran inventados para vivificar la narración, pueden servir en algunos casos en que tengamos la versión original para saber cuán lejos fue la reconstrucción del historiador. "'True or truth-like', there's the rub. More precisely, the 'rub' lies in the role of inventio in the construction of narrative; the invented speeches that enliven ancient histories are relatively unproblematic, although it is naturally of interest, where possible... to see how closely the historian's composition matches the original speech. The basic questions are: How far from the truth does truth-like take us? And will we know when we have been taken?" (Damon, 2007, p. 440).

${ }^{31}$ En otras palabras: "narratio was inherently tendentious". (Damon, 2007, p. 441). 
yendo más allá de la inventio, cayera en la mera invención de hechos. ${ }^{32}$ Es decir que, aunque no se puede afirmar que lo que exponen los historiadores antiguos es verdad, no obstante hay que considerar que ellos construían sus narrativas sobre datos que consideraban confiables. ${ }^{33}$ Finalmente, a través de un ejemplo tomado de La Guerra de las Galias de Julio César, Damon afirma que es posible generalmente reconocer qué parte de un texto es información, cuál procede de inferencias y cuál es invención. ${ }^{34}$ Es decir, a diferencia de Wiseman, Woodman y Moles y en concordancia con Cornell, Damon considera que sí podemos saber cuándo la inventio ha dejado su lugar a la mera invención.

Unos años antes del trabajo de Damon, en 2003, A. B. Bosworth publicó un extenso artículo en el que critica a investigadores de la aproximación literaria por relegar a un mero tópos la afirmación de que la verdad es el primer deber del historiador entre los autores grecolatinos. ${ }^{35}$ Bosworth sostiene que, para la organización del tema, los historiadores sí seguían los principios de la inventio y que esto los asemejaba a los oradores, pero los primeros a diferencia de los segundos se veían constreñidos por la verdad. Allí es donde se advierte la implicancia de los fundamenta a los que hacía alusión Cicerón. ${ }^{36}$ A partir de allí, Bosworth critica a Woodman, quien afirma que para Cicerón había solo dos criterios -gratia y simultas- a partir de los cuales se determinaba que el historiador se alejaba de la verdad, es decir, que era parcial. Para Bosworth, en cambio, la concepción de verdad no se agota en la imparcialidad:

"Rather there is a series of four separate but related criteria, each marked off by the connective ne. The first is a blanket demand for truth, the second the inclusion of all relevant material, the third and fourth the avoidance of prej-

\footnotetext{
32 Damon (2007, pp. 440-443).

33 "... I am not arguing that the ancient historical narratives are true... but rather that historians based their narratives on what they could (and often did) claim to be reliable information where that was possible." (Damon, 2007, pp. 447-448).

34 “This brief survey (sobre la huida de Teutomato ante el rápido asalto de las tropas romanas; Caes. Gal. VII.46.5) suggests that it is generally possible to separate the threads that make up Caesar's narrative fabric, to know, that is, whether the particular thread you are pulling is information, or inference, or coloring. Inventio is responsible for all of it, invention for some. What does this lead us to say about historical reliability and the role of rhetoric? Much of the narrative meets the criterion of 'if it happened, could Caesar have known about it?' Some events, however, rest on a foundation of logic, not knowledge, and their details are plausible, not authentic. Still others flesh out commonplaces. And some seem to have sources whose scope and reliability cannot now be ascertained. But for very few is the verdict 'ben trovato.' Episodes such as Teutomatus' nap can be discarded without much harm to our understanding of the history of 52 BCE. But what reader wants to discard this or any of the fruits of the union of rhetoric and historiography?" (Damon, 2007, p. 450). Si bien no se aceptan los comentarios de César como obras históricas, sí se puede considerar que ya en ellas podemos identificar elementos propios de la historiografía (von Albrecht, 1997, pp. 396-397), por lo cual, aceptamos el ejemplo de Damon.

${ }^{35}$ Bosworth (2003, p. 167). La misma denuncia había sido hecha en el contexto de la historiografía griega en la década precedente por Rhodes (1994). Este tipo de denuncias no se restringen a la cuestión de la verdad. Edwards (2002, p. 141) ya había enfatizado la importancia de ir más allá de la simple declaración de un tema como tópos. Ver también: Ogilvie (1970, p. 23). Sobre los tópos que no son mera retórica ver también Dench (2005, p. 45). Algunos ejemplos de declaraciones de historiadores latinos de que no se apartarán de la verdad encontramos en: Sal. Cat. 4.2, Hist. I.6; Tac. Ann. I.1.3, Hist. I.1.

${ }^{36}$ Cic. de Orat. II.62-64.
}

Anuario de la Escuela de Historia Virtual - Año 9 - No 14 - 2018: pp. 5-25. ISSN: 1853-7049 
udice, favorable and unfavorable. All four come under the general heading of veracity, but they are separate aspects. Factual reporting and the avoidance of prejudice are clearly related, but the former is a wider, more inclusive concept". ${ }^{37}$

Bosworth señala que en la escritura de una época de la historia sobre la que ya otros habían escrito, los historiadores grecolatinos no inventaban hechos. ${ }^{38}$ Más bien, trabajaban con material ya existente criticando a sus fuentes y combinando datos encontrados en varios predecesores para presentar una interpretación diferente de las existentes hasta el momento, pero no inventaban información. Ciertas exageraciones no serían inventos posteriores, sino que podríamos rastrearlas hasta aquellos que escribieron contemporáneamente a los hechos, si bien esto no niega que aquellos que escribieron sobre hechos contemporáneos podían haberlo hecho de un modo parcial. De todos modos, los que se servían de dicha información posteriormente no eran meros copistas, por lo que, si bien podían llegar a reproducir dicha versión, esa era una elección que asumía el historiador en su reinterpretación de ese pasado, la que guardaba relación tanto con la tesis que buscaba cimentar, como con la enseñanza moralizante que pretendía ofrecer a su audiencia a través de ese pasaje. ${ }^{39}$

De este modo, dos puntos importantes debemos retomar del trabajo de Bosworth: primero, que no hay que considerar la declaración de verdad que hacían los historiadores como un mero tópos y, segundo, que es relevante rescatar el papel pensante de los historiadores en la construcción de la interpretación que ofrecen. Este último aspecto acerca la práctica historiográfica a la oratoria judicial.

No obstante, dada la escasa citación de fuentes que encontramos en las obras griegas y latinas cabe preguntarnos: ¿qué es lo que da credibilidad a una interpretación? Más importante resulta este interrogante si consideramos que la verdad es algo tan maleable en la narración como aseveran aquellos investigadores alineados con la aproximación literaria postmoderna. Marincola ha mostrado que aquella se logra a través de una serie

\footnotetext{
${ }^{37}$ Bosworth (2003, p. 169).

${ }^{38}$ La comparación entre la imagen de Timeo que nos da Polibio y la que tendríamos de J. G. Droysen si su Geschichte Alexanders des Großen no hubiera sobrevivido y solo dispusiéramos de la reseña hecha por K. W. Krüger del mismo, resulta muy interesante para matizar ciertas tesis extremistas que se defienden sobre autores que no disponemos; ver: Bosworth (2003, p. 193). Incluso, este estudio de Bosworth es útil para llamar la atención, una vez más, sobre aquellos que tienden a atribuir a autores, cuyas obras no nos han llegado, opiniones e interpretaciones que nos son transmitidas por historiadores, como Tito Livio, cuyas obras sí se han conservado.

${ }^{39}$ Bosworth (2003, p. 194). Bosworth (2003, pp. 194-195) culmina con un ejemplo claro, que vale la pena citar: "The ancient source tradition on Alexander's marriage to Rhoxane, for instance, is reasonably consistent in its factual outline and contextual framework, but the incident can be represented negatively as Alexander succumbing to barbarian mores or positively as Alexander virtuously waiving the rights of the conqueror. In both cases the interpretation is clear and easily separable, and, it can be argued, the two views are not mutually exclusive and may themselves go back to opinion contemporaneous with Alexander. This is history as re-interpretation. Reportage and opinion are selected, adapted, and woven together in a new blend with a different emphasis. It is modification certainly, at times transformation: it is not independent, systematic, and self-conscious fiction".
} 
de prácticas retóricas, ${ }^{40}$ que ponen de manifiesto en la misma obra la competencia del historiador para narrar y explicar el pasado. Dentro de esas prácticas retóricas está incluida la construcción de una persona que resulte persuasiva y creíble para los lectores. ${ }^{41}$ Todo lo cual está inserto en una tradición historiográfica, con la que el propio historiador se vincula para posicionar su persona y su obra con respecto a aquellos que han tenido éxito anteriormente en ella, a fin de construir su auctoritas. ${ }^{42}$

\section{¿Una interpretación moral?}

"Roman cultural identity is...heavily moral in its focus: that is to say that our own categories of culture and morality blur nicely within the Roman formula of... mores maiorum." (Dench, 2005, p. 139).

Por lo dicho hasta aquí, podemos afirmar que en cierta medida las dos aproximaciones que citamos al comienzo del apartado tienen su parte de razón. La historiografía latina es una rama de la retórica y, más aún, el método histórico tiene su vinculación con la oratoria judicial, pues, el historiador debe presentar una interpretación del pasado que resulte convincente $\mathrm{y}$, al mismo tiempo, le confiera auctoritas como narrador. Así como el orador, el historiador debe ponderar algunos hechos, reordenar otros y descartar aquellos datos que no considere pertinentes en su interpretación. ${ }^{43}$

Esto no debe llevarnos a pensar, sin embargo, que la declaración que hacen los autores de que dirán la verdad en sus obras es un simple lugar común. ${ }^{44}$ Como pudimos observar en el repaso anterior, la propia auctoritas del historiador podía verse comprometida si era encontrado culpable de tergiversar los hechos descaradamente. En el caso de hechos cercanos en el tiempo, la denuncia podía ser hecha por alguien que hubiera estado presente en los acontecimientos relatados. Por supuesto, el peso de esta resultaba mayor si era un personaje de mucha auctoritas quien la realizaba. En el caso de sucesos más

\footnotetext{
${ }^{40}$ Algunas explícitas, como son aquellas en las que se concentra Marincola (2004), y otras implícitas, como, por ejemplo, el estilo.

41 "The highly stratified societies of Greece and Rome cared a great deal about the status of the speaker. The proof that things are as the historian says they are depended not a little on the audience's perception of the narrator's character: to believe an historical account, it was necessary to believe the historian himself". (Marincola, 2004, p. 6).

42 "... that it is no exaggeration to say that the appeal to tradition is itself a part of the historian's authority, for it is a shorthand used by the historian to identify his interest, approach, and alliances". (Marincola, 2004, p. 19). Y, más adelante agrega: “As certain historians became accepted models for imitation, their concerns and approach dictated for those who followed the proper way to write history. As the earlier historians were 'authoritative', so their followers sought to imitate the manner by which those predecessors had constructed their own authority. It was in this way that authority and tradition were closely related, and so long as the belief in imitation held sway, there could be no authority outside of tradition". (Marincola, 2004, p. 258).

${ }^{43}$ Ver: Nicolai (2007, pp. 21-22); Damon (2007, pp. 440-443). Para una posición diferente, véase: Lendon (2009, pp. 55-56).

${ }^{44}$ Ver: Nicolai (2007, p. 21).
}

Anuario de la Escuela de Historia Virtual - Año 9 - No 14 - 2018: pp. 5-25. ISSN: 1853-7049 
lejanos en el tiempo, otro historiador podría detectar una modificación no justificada con respecto a fuentes precedentes para polemizar con el autor criticado. ${ }^{45}$ Asimismo, puesto que la historia tenía una incidencia importante en la vida política del presente, también un político podía señalar las inexactitudes que encontrara en una obra. ${ }^{46}$ Esta implicancia de la historia en el presente se pone de manifiesto también en las denuncias que podemos encontrar sobre la alteración que hacían algunos del pasado de la gens durante las oraciones fúnebres. ${ }^{47}$ Teniendo en cuenta este marco, resultaría llamativo, como señalan Cornell y Damon, que un historiador pudiera inventar descaradamente información.

Ahora bien, al considerar el tema de la verdad en la historiografía antigua, no debemos dejar de considerar otros aspectos, como son los objetivos que perseguían las obras históricas, puesto que estos guardan estrecha relación con la construcción de interpretaciones por parte de los escritores, tal y como hemos advertido en algunas de las argumentaciones citadas.

Un punto relevante que cabe señalar aquí es que en la antigüedad grecorromana no había una formación específica para ser historiador. La historia, como otros géneros literarios, formaba parte de la educación retórica. ${ }^{48}$ De este modo, así como no debemos considerar la historia como un género totalmente separado del resto ${ }^{49}$ tampoco debemos

${ }^{45}$ Como en el caso de la crítica de Tito Livio a Licinio Macro en Liv. VII.9.3-6.

${ }^{46} \mathrm{Si}$ bien no precisa cuáles eran las inexactitudes que encontraba Calígula en Tito Livio, Suetonio (Cal. XXXIV) menciona una crítica de aquel a este por ello. Claramente, la referencia está en el marco de una crítica a Calígula, pero sirve de ejemplo para observar que la práctica existía. La preocupación de los historiadores por citar las diferentes versiones ante posibles críticas también puede advertirse, por ejemplo, en el caso de la narración que ofrece Tito Livio de los segundos despojos ópimos (IV.20.1-11, 32.4). Siguiendo a Luce (1965, pp. 211-218, 232), vemos que el autor hizo una inclusión posterior (IV.20.5-11) a su escrito primigenio para asentar la versión que Augusto habría hecho pública luego de restaurar el templo de Júpiter Feretrio y en un contexto de disputa política con Licinio Craso, procónsul que había dado muerte al jefe de los bastarnas y reivindicaba el honor de ofrecer los despojos al dios. El tema no carecía de importancia para Augusto, que buscaba cimentar su posición en el Estado y terminar con el enfrentamiento entre grandes hombres, acaparando en su persona diferentes aspectos que otorgaban renombre en la sociedad romana (Alföldy, 1987, pp. 138-142).

${ }^{47}$ Cic. Br. 62 y Liv. VIII.40.

${ }^{48}$ Esta cuestión de la formación de los historiadores es aceptada por los investigadores actuales y, asimismo, lo es la presencia de la retórica, aunque, como hemos señalado, en diferentes grados de importancia. En ese marco, la idea de que la historia es una rama de la retórica no es aceptada por todos. A favor de esta tesis, por ejemplo, encontramos a Woodman (2004, pp. X, 100 y passim) y Nicolai (1992, pp. 89-155). Entre los que no están de acuerdo, podemos nombrar a Oakley (2004, p. 7) y Lendon (2009, pp. 51-54).

${ }^{49} \mathrm{El}$ grado de difuminación o rigurosidad de las fronteras del género historiográfico grecolatino es motivo de debate aún. Wiseman (1987, p. 261); Woodman (2004, p. 100) y quienes adscriben a la aproximación literaria enfatizan un alto grado de fluidez de las fronteras con la poesía, épica especialmente, y el drama, ver: Kraus y Woodman (1997, pp. 3, 5). En la misma línea se posicionan Clarke (2002, pp. 22 y ss.) y Engels (2007, pp. 541, 543) en lo que atañe a la relación entre geografía e historiografía. Sin embargo, Clarke aclara que los investigadores deben mantenerse alerta sobre los parámetros que se toman en cada contexto para definir cada disciplina geográfica e historiográfica. La misma posición y cautela defiende Nicolai (2007, pp. 20-21), quien enfatiza la idea de que la historiografía no es un género estático en el mundo grecorromano, sino que podemos observar su evolución a lo largo del tiempo (Nicolai, 2007, p. 18). Esos cambios tienen incidencia en diferentes aspectos de la práctica historiográfica que se relacionan con la cuestión de la verdad y, por ello, Nicolai (2007, p. 19) subraya que, en lugar de considerar ciertas pautas o concepciones como válidas para juzgar a todos los autores: "The only possibility is to leave open the borders of the historiographical genre, distinguishing from time to time the goals of individual authors and judging their

Anuario de la Escuela de Historia Virtual - Año 9 - N 14 - 2018: pp. 5-25. ISSN: 1853-7049 
atribuirle los patrones científicos actuales. ${ }^{50}$ Como se ha ido observando a medida que avanzamos en la temática, los objetivos de las obras históricas grecolatinas distan de ser como los que rigen la disciplina hoy en día. En ese marco, vemos que historiadores que tratan hechos que ya habían sido estudiados no siempre retoman dicho tema para agregar nueva información, sino que hay casos en que el historiador se limita a retomar imparcialmente las versiones disponibles para luego elaborar una interpretación diferente, como señala Bosworth. ${ }^{51}$ Con ello, se pone de manifiesto la finalidad didáctica de la historia. Es decir, los historiadores buscaban presentar modelos de conducta para sus lectores. Para lograrlo, sus interpretaciones se orientaban a la configuración de exempla, principalmente, morales y político-militares, que también podemos considerar como un tipo dentro de los morales. ${ }^{52}$

Al considerar el peso de la moral en los fines que tiene la práctica historiográfica latina, no debemos dejar de pensar en aquello que señalamos al comienzo del artículo acerca de la historia como un reflejo del modo en que los propios romanos concebían y daban sentido al mundo.

La moral -y las costumbres-, en latín mores, no se entendía entre los romanos como una cuestión separada de otras como la política o la economía, sino que, como señala C. Edwards, eran percibidas como categorías que se superponían. De allí que lo que nosotros interpretamos como problemas políticos o económicos, los romanos lo explicaban en términos de ambición o codicia de tales o cuales individuos. ${ }^{53}$ También la religión guardaba relación con la moral de los dirigentes romanos, quienes, según se comportaran piadosa o impiadosamente con los dioses, podían, en el primer caso,

works not in terms of a canon, either Thucydidean or modern as it may be, but in the context that produced them and that they served". La historiografía como un género con límites más rigurosos es defendida, por ejemplo, por Lendon (2009, pp. 53-54).

50 Tampoco, consideramos, debemos seguir a Batstone, quien, luego de afirmar “... the Roman historians were also historians, and they were no more modernist historians (telling us what happened, what really happened, objectively, truthfully) than they are postmodern historians", extrae como una consecuencia lógica, a nuestro juicio injustificadamente, que los historiadores griegos y romanos deben ser agrupados dentro de los segundos (i!) y sus textos analizados dentro de dicha concepción: "Which means that we have just as much of a right and an obligation to read them from a postmodern perspective as earlier generations had to read them within the norms and requirements of modernist history. Furthermore, doing this we may see that in some ways they have already been where we are going..., which means that there are things going on in these writers that we may only now be able to appreciate, and that they may help us see new ways to write history today." Ver: Batstone (2009). Para la primera cita ver p. 30; sobre este punto, consultar también p. 25; para la segunda cita, ver: pp. 30-31. No negamos, como se advierte en nuestra exposición, que las teorías postmodernas nos han permitido advertir y profundizar algunos aspectos de la historiografía grecolatina que antes no éramos capaces de notar, pero al realizar tal aseveración Batstone comete un error al posicionarse en el otro extremo y reproducir desde una posición postmodernista aquello que le critica a los modernistas. Al considerar como pares postmodernistas a Salustio, César o Tito Livio, Batstone pasa por alto los diferentes contextos culturales, el suyo y el de las fuentes.

51 Véase también: Marincola (2004, pp. 95-117, 280-286; 2009, pp. 18-19). Un ejemplo interesante es el que proporciona la reconstrucción que lleva a cabo D. Musti de las fuentes que estarían detrás de la posición filoetrusca de Tito Livio y de la anti etrusca que presenta Dionisio de Halicarnaso; ver: Musti (1970).

52 Ver, por ejemplo: Cizek (1985, p. 33); Nicolai (2007, pp. 14, 16); Stadter (2009); Hedrick (2009); Marincola (2009) y Moreno (2014). Ya hemos citado al comienzo la opinión de Walsh sobre Tito Livio.

${ }^{53}$ Edwards (2002, pp. 3-4, 21-22).

Anuario de la Escuela de Historia Virtual - Año 9 - No 14 - 2018: pp. 5-25. ISSN: 1853-7049 
18 I La moral en la interpretación del pasado en la historiografía latina

asegurar el favor de estos y, por ello, las victorias sobre los enemigos, o, en el segundo caso, atraer la ira de los dioses con consecuencias terribles para la comunidad, como, por ejemplo, una guerra civil. Más aún, como resaltan A. Wallace-Hadrill y E. Dench, podemos advertir, de un modo más general, que la cultura y la moral se encontraban solapadas en la idea romana de mores. ${ }^{54}$

De este modo, en tanto que medio a través del cual se leían los cuerpos y se entendían y juzgaban las acciones de los vires en ese "bosque de ojos" que era la sociedad romana, ${ }^{55}$ los mores tenían un lugar fundamental en las instancias de representación y negociación de las relaciones de poder:

"Attacks on immorality were used by the Roman elite to exercise control over its own members and to justify its privileged position. Roman moral norms... were norms which were not deduced from any universal principle but which were, to a certain degree, internalised by members of the society which used them". ${ }^{56}$

Esa internalización de los mores de los ancestros, mores maiorum (mos maiorum, en singular), marca la vinculación de aquellos con la tradición y, al mismo tiempo, los presenta como una carga "casi genética" que pasa de generación en generación. ${ }^{57}$ De este modo, los mores guardan relación con la definición de la identidad de la élite y, asimismo, inextricablemente vinculada con ella, de la identidad romana que lograra mayor aceptación en un período determinado de su historia. En la medida en que dicha definición estaba en constante negociación, no podemos hablar de una identidad romana estática y válida para toda la historia romana. ${ }^{58}$ De todas maneras, más allá de los cambios, en las fuentes -y no solo en las históricas- de los diferentes períodos podemos encontrar reflexiones moralizantes destinadas a ofrecer exempla que recomienden códigos de conducta adecuados para aquellos que pretendan formar parte de la élite, ${ }^{59}$ grupo aristocrático que representa la audiencia principal de las obras históricas. ${ }^{60}$ Ese nexo entre élite y moral ocupa, como señalamos, un lugar fundamental al interior de la sociedad, pero también en la definición de la identidad frente a los demás pueblos.

\footnotetext{
${ }^{54}$ Wallace-Hadrill (1997; 2008, pp. 32-35 y 213-258) y Dench (2005, pp. 44-45, 65-69, 139).

${ }^{55}$ La imagen del "bosque de ojos" es de M. Gleason (Kaster, 1997, p. 11). Sobre este punto y otros al respecto de la lectura del cuerpo en el mundo romano, ver: Gunderson (1998); Edwards (2002); Barton (2002) y Diez et al. (2011, pp. 7-33).

${ }_{56}$ Edwards (2002, p. 4).

${ }^{57}$ Ver: Wallace-Hadrill (1997, p. 8), a quien pertenece la idea entrecomillas; Dench (2005, p. 66). Resulta también interesante en este punto la propuesta de Richardson (2012), quien analiza la caracterización similar del comportamiento de los gentiles que encontramos en las fuentes literarias (v.g. los Claudii eran arrogantes y odiaban a la plebe, los Manlii eran severos, los Iunii Bruti campeones de la libertad, etc.), aseverando que allí no debemos ver solo un recurso literario, sino reconocer una manera romana de pensar: "It appears to be a central component of the way in which the Romans thought about families and about human behaviour in the context of the family, and consequently of the way in which they thought about the past". (Richardson, 2012, p. 52).

${ }^{58}$ Ver, por ejemplo: Wallace-Hadrill (1997 y 2008, pp. 213-258).

${ }^{59}$ Edwards (2002, pp. 16-17).

${ }^{60}$ Marincola (2009, p. 22). Pero también obviamente otras audiencias, incluso por debajo de la élite, como lo remarca también para el caso del discurso ejemplar Roller (2004, p. 6).
}

Anuario de la Escuela de Historia Virtual - Año 9 - N 14 - 2018: pp. 5-25. ISSN: 1853-7049 
Porque la superioridad moral que los propios romanos se atribuyen -al menos muchos de entre ellos- es la que en su concepción justifica la supremacía sobre los otros, cuya representación guarda relación con una tradición etnográfica, en la que el ethos de un pueblo se ve influenciado por el locus que habita. ${ }^{61}$

En ese sentido, no debe extrañarnos que las interpretaciones que encontramos en las obras históricas latinas, las argumentaciones, las afirmaciones, las críticas sean presentadas a través del prisma de la moral, ya sea en lo político, ya sea, incluso, lo religioso, cuando se acusa a un historiador de parcial, ${ }^{62}$ puesto que la realidad era entendida en esos términos. ${ }^{63}$ Son los exempla, inherentemente morales, los que sirven a los romanos para reflexionar sobre su pasado y, al mismo tiempo, ya sea aceptando, ya sea contestando la interpretación que se les ofrece de las acciones memorables en esos exempla, configurados en esas obras histórica o por otros medios, que ellos actuarán, emulando las acciones virtuosas y evitando las viciosas. Es interesante sobre este punto la propuesta de M. B. Roller sobre el discurso ejemplar en la cultura romana, según el cual, una acción es interpretada por una audiencia que la juzga significativa ética y socialmente y la asocia a una virtud en la que la categoriza. De este modo, al ser un hecho significativo para la comunidad, esa acción es conmemorada en un monumento, que puede servir de acicate a una nueva audiencia, que pretenderá imitar la acción virtuosa, lo que daría lugar a un nuevo comienzo del proceso desde la primera instancia. ${ }^{64}$

En la medida en que es en términos morales que los romanos pensaban el mundo, es decir, que le daban sentido, es un error considerar las narraciones de las obras históricas como mera ficción, ${ }^{65}$ dado que, al reflejar su forma de interpretar el mundo, esta para los

\footnotetext{
${ }^{61}$ Ver: Thomas (1982, pp. 1-7), quien reconoce el lugar del aspecto moral en dicha tradición en Roma. 62 Sobre este último punto, véase Luce (1989, pp. 21-22).

${ }^{63}$ Siguiendo a Edwards, Wallace-Hadrill y otros, Dench $(2005$, p. 45) asevera: "It is... important not to conclude that we are 'only' dealing with rhetoric... Rhetoric necessarily engages with issues of contemporary resonance. We should be wary of dismissing ancient explanatory frameworks for the rise and fall of 'empires' for example, such as lust and luxury, and of imposing instead our own, more 'sensible' (but also entirely culturally determined) explanations, such as economic motives for expansion. On the contrary, assumptions about the moral problem of empire were the basis upon which opinion could be swayed and manipulated, and action taken".

${ }^{64}$ Roller (2004).

${ }^{65}$ Nos apartamos aquí, por tanto, de la tesis de Levene (2010). Levene en su análisis sobre la tercera década de la obra de Tito Livio enfatiza la importancia de la moral como aquello que permite que la narración tenga sentido. Sin embargo, luego va más allá que nosotros y, siguiendo una lectura postmoderna, separa la realidad del pasado de la realidad del pasado construida en la Historia Romana. Para Levene, el escritor paduano presenta en esa década secuencias narrativas que son imposibles, pero lo que aún llama más la atención es que el propio historiador romano ponga en evidencia dicha imposibilidad (incluso, sin mencionar sobre la dificultad de obtener información sobre el período en cuestión). De todas formas, la narrativa que surge de la composición de Tito Livio sería una combinación de versiones, que, si bien por separado son falsas, en conjunto se complementan reconstruyendo una realidad pasada que, igualmente, no pudo haber ocurrido. Es decir, ninguna de ellas tendría sentido sin la información que pertenece a otra. En esa construcción lo que le importaría al historiador romano es el objetivo moral y político que tiene en mente para su obra: "But there is little doubt that for Livy it is morality that matters above all. His self-presentation centres on showing himself as a provider of ethical lessons, and... he highlights his presentations of causation in ethical terms, and the reader is forced to interpret it in those terms not least because it is so hard to make sense of it in any other terms. Livy's world is an ethical world: it is also a real world. But the real world is one where causal sequence, chronology, human behaviour and everything else are subordinated to
} 
romanos era una explicación válida. Es decir, la misma era en sus términos una reconstrucción verosímil de los hechos pasados. Claro está, esto trae sus inconvenientes para los investigadores actuales que quieren leer la historia con otro prisma, con otra concepción de la realidad. ${ }^{66}$ Ante ello, el historiador moderno debe buscar en las fuentes datos que le permitan construir una interpretación del pasado que sea significativa en sus propios términos. Pero sin dejar de tener presente que las narraciones históricas que analiza están escritas según otros criterios interpretativos. ${ }^{67}$

\section{Conclusión}

El estado de la cuestión presentado en la primera parte nos permitió, en la segunda parte del artículo, establecer nuestra posición en torno a ciertos aspectos discutidos en el debate. En este marco, y con el fin de enriquecer el análisis, nos pareció pertinente sacar a colación algunos aportes que se han realizado en los estudios sobre la cultura romana en las últimas décadas. Estos han puesto de manifiesto el papel central de la moral como tamiz mediante el cual la realidad es entendida por los romanos. A partir de allí, nuestro planteo sugiere que es en esos mismos términos morales que los historiadores construían sus lecturas de los hechos. En ese sentido, aquella apreciación de Walsh de que Tito Livio había falsificado la historia intencionalmente, no por error, es incorrecta, puesto que la interpretación moral de la misma no es algo exclusivo de este autor, sino un aspecto de la cultura de la sociedad en la que este escribe su obra.

Nuestra dificultad para comprender en todas sus dimensiones ese otro modo de entender el mundo es lo que da pie a nuestros juicios sobre dichas narraciones, a las que catalogamos como verosímiles o ficcionales a partir de nuestra forma de pensar la realidad. Estos mismos juicios marcan de manera flagrante la distancia que separa aquel modo de hacer inteligible el mundo del nuestro. Allí radica, posiblemente, nuestra dificultad de creer en las declaraciones que aducen los historiadores romanos de que narran la verdad.

Tal vez, el reconocer la relevancia de la moral en la cultura romana y partir de este presupuesto al plantear nuestros análisis de los distintos aspectos que atañen a la historiografía latina puede ser un modo de avanzar en el objetivo que Marincola plantea en la frase que hemos tomado como epígrafe. Esto es, profundizar nuestra comprensión de las cuestiones que le daban sentido a la práctica historiográfica entre los propios romanos.

\footnotetext{
the moral structure that Livy offers, and which he implies is also the moral structure of the universe. Ethics effectively controls everything else. The ultimate understanding of how Livy can present his text, with its self-acknowledged contradictions, as if it were reality, may be that he regards the moral picture that his text presents as a valid account in its own right, but also an accurate demonstration of the way the world works. By reading through they are -and one is obliged to focus on morality precisely because here is no other way of making sense of that text. And it is in those lessons, for him, that the truth of the Hannibalic War resides." (2010, p. 392).

${ }^{66} \mathrm{O}$, en términos de Cabrera (2005), leer la historia a partir de otra construcción significativa de la realidad. ${ }^{67}$ En términos kuhnianos (Kuhn, 2010) diríamos que los romanos emplean un paradigma diferente al nuestro para entender la realidad que los rodea.
}

Anuario de la Escuela de Historia Virtual - Año 9 - N 14 - 2018: pp. 5-25. ISSN: 1853-7049 


\section{Referencias bibliográficas:}

Alföldy, G. (1987). Historia social de Roma. Madrid: Alianza Editorial.

Barton, C. (2002). Being in the eyes. Shame and Sight in Ancient Rome. En D. Fredrick (Ed.). The Roman Gaze. Vision, Power, and the Body. Baltimore-London: The Johns Hopkins University Press.

Batstone, W. W. (2009). Postmodern historiographical theory and the Roman historians. En A. Feldherr (Ed.). The Cambridge companion to the Roman Historians (pp. 24-40). Cambridge: Cambridge University Press.

Bayet, J. (1958 (19401)). Tite-Live. Histoire Romaine, Tome. I, Livre I. Paris: Les Belles Lettres.

Bosworth, A. B. (2003). Plus ça change...Ancient Historians and their Sources. Classical Antiquity, 22 (2), 167-198.

Briscoe, J. (1973). A Commentary on Livy. Books XXXI-XXXIII. Oxford: Clarendon Press.

Briscoe, J. ([1981] 2003). A Commentary on Livy. Books XXXIV-XXXVII. Oxford: Clarendon Press.

Briscoe, J. (2008). A Commentary on Livy. Books 38-40. Oxford: Oxford University Press.

Briscoe, J. (2012). A Commentary on Livy. Books 41-45. Oxford: Oxford University Press.

Brunt, P. A. (1979). Cicero and Historiography. En Philias charin. Miscellanea di studi classici in onore di Eugenio Manni. Tomo I (pp. 309-340). Roma: Giorgio Bretschneider.

Cabrera, M. Á. (2005). Hayden White y la teoría del conocimiento histórico. Una aproximación crítica. Pasado y Memoria. Revista de Historia Contemporánea, 4, 117-146.

Cizek, E. (1985). Les genres de l'historiographie Latine. Faventia: Revista de Filología Clásica, 7 (2), 15-34.

Clarke, K. (2002). Between Geography and History. Hellenistic Constructions of the Roman World. Oxford: Clarendon Press.

Cornell, T. J. (1982). Review: Clio's Cosmetics: Three Studies in Greco-Roman Literature by T. P. Wiseman. The Journal of Roman Studies, 72, 203-206.

Cornell, T. J. ([1995] 1999). Los orígenes de Roma c. 1000-264 a.C. Italia y Roma de la Edad del Bronce a las guerras púnicas. Barcelona: Ed. Crítica.

Cornell, T. J. ([1986] 2005). The Value of the Literary Tradition Concerning Archaic Rome. En K. A. Raaflaub (Ed.). Social Struggles in Archaic Rome. New Perspectives on the Conflict of the Orders (pp. 47-74). Malden-Oxford-Victoria: Blackwell Publishing Ltd.

Damon, C. (2007). Rhetoric and historiography. En W. Dominik y J. Hall (Eds.). A Companion to Roman Rhetoric (pp. 439-450). Malden/MA-Oxford: Blackwell Publishing Ltd.

Diez, V. et al. (2011). Cuerpos (d)escritos. En A. Schniebs (Coord.). Discursos del cuerpo en Roma (pp. 7-39). Buenos Aires: Editorial de la Facultad de Filosofía y Letras. Universidad de Buenos Aires.

Drijvers, J. W. (1998). Ammianus Marcellinus on the Geography of the Pontus Euxinus. Histos, 2, 268-278.

De Foucault, J.-A. (1968). Tite-Live traducteur de Polybe. Révue des Études Latines, 46, 208221.

Anuario de la Escuela de Historia Virtual - Año 9 - No 14 - 2018: pp. 5-25. ISSN: 1853-7049 
22 | La moral en la interpretación del pasado en la historiografía latina

Dench, E. (2005). Romulus' Asylum. Roman Identities from the Age of Alexander to the Age of Hadrian. Oxford: Oxford University Press.

Edwards, C. ([1993] 2002). The Politics of Immorality in Ancient Rome. Cambridge: Cambridge University Press.

Engels, J. (2007). Geography and history. En J. Marincola (Ed.). A companion to Greek and Roman historiography. Vol. I (pp. 541-552). Malden-Oxford-Victoria: Blackwell Publishing.

Feeney, D. C. (2007). The History of Roman Religion in Roman Historiography and Epic. En J. Rüpke (Ed.), A companion to Roman religion (pp. 129-142). Malden-Oxford-Victoria: Blackwell Publishing Ltd.

Fontán, A. (1984). El griego de Tito Livio. Estudios Clásicos, 26 (88), 311-322.

Frier, B. W. (1990). Review: Rhetoric in Classical Historiography: Four Studies. The American Historical Review, 95 (2), 461-462.

Ginzburg, C. (2014). Unus Testis. En C. Ginzburg, El Hilo y las huellas. Lo verdadero, lo falso, lo ficticio (pp. 297-326). Buenos Aires: Fondo de Cultura Económica.

Ginzburg, C. (2014). Apéndice. Pruebas y posibilidades. En C. Ginzburg, El Hilo y las huellas. Lo verdadero, lo falso, lo ficticio (pp. 433-465). Buenos Aires: Fondo de Cultura Económica.

Goodyear, F. R. D. (1966). Review: Livy i-v. The Classical Review, 16 (1), 60-63.

Gunderson, E. (1998). Discovering the Body in Roman Oratory. En M. Wyke (Ed.). Parchments of Gender. Deciphering the Bodies of Antiquity (pp. 169-189). Oxford: Clarendon Press.

Haverfield, F. (1911). An inaugural address delivered before the first annual general meeting of the society, 11th May, 1911. The Journal of Roman Studies, 1, xi-xx.

Hedrick, Ch. W. Jr. (2009). Imitating Virtue and Avoiding Vice: Ethical Functions of Biography, History, and Philosophy. En R. K. Balot (Ed.). A companion to Greek and Roman political Thought (pp. 421-439). Malden/MA-Oxford: Blackwell Publishing Ltd.

Jaeger, M. (1997). Livy's Written Rome. Ann Arbor: The University of Michigan Press.

Kaster, R. A. (1997), The shame of the Romans. Transactions of the American Philological Association 127, 1-19.

Kraus, C. S. y Woodman, A. J. (1997). Latin historians. Glasgow: Oxford University Press.

Kuhn, T. S. (2010). La estructura de las revoluciones científicas. México: Fondo de Cultura Económica.

Lendon, J. E. (2009). Historians without history: against roman historiography. En A. Feldherr (Ed.). The Cambridge Companion to the Roman Historians (pp. 41-61). Cambridge: Cambridge University Press.

Linderski, J. (1993). Roman Religion in Livy. En W. Schuller (Ed.). Livius: Aspekte seines Werkes (pp. 53-70). Konstanz: Xenia.

López Ramos, J. A. (2008). Excursus, etnografía y geografía: un breve recorrido por la tradición historiográfica antigua (de Heródoto a Amiano Marcelino). Nova Tellus, 26 (1), 259-319. 
Luce, T. J. (1965). The Dating of Livy's First Decade. Transactions and Proceedings of the American Philological Association, 96, 209-240.

Luce, T. J. (1977). Livy. The Composition of His History. Princeton: Princeton University Press.

Luce, T. J. (1989). Ancient views on the causes of bias in historical writing. Classical Philology, 84 (1), 16-31.

Marincola, J. ([1997] 2004). Authority and tradition in ancient historiography. Cambridge: Cambridge University Press.

Marincola, J. ([2001] 2006). Greek Historians. New York: Cambridge University Press.

Marincola, J. (2009). Ancient audiences and expectations. En A. Feldherr (Ed.), The Cambridge Companion to the Roman Historians (pp. 11-23). Cambridge: Cambridge University Press.

Miles, G. B. ([1995] 1997). Livy. Reconstructing Early Rome. Ithaca-London: Cornell University Press.

Moles, J. L. (1993). Truth and Untruth in Herodotus and Thucydides. En G. Gill y T. P. Wismean (Eds.). Lies and fiction in ancient world (pp. 88-121). Exeter: University of Exeter Press.

Momigliano, A. (1974). Historicism Revisited. Mededelingen der Koninklijke Nederlandse Akademie van Wetenschappen, 37 (3), 63-70.

Momigliano, A. (1992). Estudios bíblicos y estudios clásicos: simples reflexiones sobre el método histórico. En A. Momigliano, De paganos, judíos y cristianos (pp. 13-24). México: Fondo de Cultura Económica.

Moralejo, J. L. (2002). Tácito, Anales. Libro I-VI. Madrid: Gredos.

Moreno, A. (2014). Los cartagineses en la reflexión político moral del Bellum Iugurthinum. Ágora. Estudos Clássicos em Debate, 16, 41-60.

Musti, D. (1970). Tendenze nella storiografia romana e greca su Roma arcaica: studi su Livio e Dionigi d'Alicarnasso. Quaderni Urbinati di Cultura Classica, 10, 3-159.

Nicolai, R. (1992). La storiografia nell'educazione antica. Pisa: Giardini.

Nicolai, R. (2007). The Place of Ancient History in the Ancient World. En J. Marincola (Ed.), A Companion to Greek and Roman Historiography. Vol. I. (pp. 13-26). MaldenOxford: Blackwell Publishing Ltd.

Oakley, S. P. ([1997] 2004). A commentary on Livy. Books VI-X. Volume I: Books VI. Oxford: Oxford University Press.

Ogilvie, R. M. ([1965] 1970). A Commentary on Livy. Books 1-5. Oxford: Clarendon Press.

Paul, G. M. (1984). A Historical Commentary on Sallust's Bellum Jugurthinum. Liverpool: Francis Cairns.

Requejo, J. M. (1981). Tácito, Agrícola-Germania-Diálogo sobre los oradores. Madrid: Gredos. Rhodes, P. J. (1994). In Defence of the Greek Historians. Greece \& Rome, 41 (2), 156-171.

Richardson, J. H. (2012). The Fabii and the Gauls. Studies in historical thought and historiography in Republican Rome. Stuttgart: Franz Steiner Verlag.

Roller, M. B. (2004). Exemplarity in Roman Culture: The Cases of Horatius Cocles and Cloelia. Classical Philology, 99 (1), 1-56. 
24 | La moral en la interpretación del pasado en la historiografía latina

Serna, J. y Pons, A. (2005). La historia cultural. Autores, obras, lugares. Madrid: Akal.

Stadter, P. A. (2009). Character in Politics. En R. K. Balot (Ed.), A companion to Greek and Roman Political Thought (pp. 456-470). Malden-Oxford: Blackwell Publishing Ltd.

Sundwall, G. A. (1996). Ammianus Geographicus. American Journal of Philology, 117 (4), 619-643.

Syme, R. ([1964] 1982). Salluste. Paris: Les Belles lettres.

Syme, R. ([1958] 1997). Tacitus. Vol. I. Oxford: Clarendon Press.

Thomas, F. (1982). Lands and peoples in Roman poetry. The ethnographical tradition. Cambridge: Cambridge Philological Society.

Von Albrecht, M. ([1994] 1997). Historia de la literatura romana. Desde Andrónico hasta Boecio. Vol. I. Barcelona: Ed. Herder.

Wallace-Hadrill, A. (1997). Mutatio morum: the idea of a cultural revolution. En T. Habinek y A. Schiesaro (Eds.). The Roman Cultural Revolution (pp. 3-22). Cambridge: Cambridge University Press.

Wallace-Hadrill, A. (2008). Rome's Cultural Revolution. Cambridge-New York: Cambridge University Press.

Walsh, P. G. (1955). Livy's Preface and the Distortion of History. The American Journal of Philology, 76 (4), 369-383.

Walsh, P. G. (1958). The negligent historian: 'Howlers' in Livy. Greece \& Rome, 5 (1), 8388.

Walsh, P. G. ([1961] 1963). Livy. His historical aims and methods. Cambridge: Cambridge University Press.

Walsh, P. G. (1982). Livy and Aims of 'historia': An Analysis of the Third Decade. En W. Haase (Ed.), Aufstieg und Niedergang der römischen Welt. Vol. II.30.2 (pp. 1058-1074). Berlin-New York: De Gruyter.

White, H. ([1973] 1992). Metahistoria. La imaginación histórica en la Europa del siglo XIX. México: Fondo de Cultura Económica.

White, H. ([1987] 1992b). El contenido de la forma. Narrativa, discurso y representación histórica. Barcelona: Ed. Paidós.

White, H. (2003). El texto histórico como artefacto literario. En H. White, El texto histórico como artefacto literario y otros escritos. Barcelona: Ed. Paidós.

Wiseman, T. P. ([1981] 1987). Practice and theory in Roman historiography. En T. P. Wiseman, Roman Studies. Literary and historical (pp. 244-262). Liverpool: Published by Francis Cairns Ltd.

Wiseman, T. P. (1988). Historiography and Rhetoric. The Classical Review, 38 (2), 262-264.

Wiseman, T. P. (1993). Lying Historians: Seven Types of Mendacity. En G. Gill y T. P. Wiseman (Eds.), Lies and fiction in ancient world (pp. 122-146). Exeter: University of Exeter Press.

Wiseman, T. P. ([1994] 1999). Historiography and imagination. Eight essays on Roman Culture. Exeter: Short Run Press Ltd.

Woodman, A. J. ([1988] 2004). Rhetoric in Classical Historiography. London-New York: Routledge. 
25 | Agustín Moreno

Para citar este artículo:

Moreno, Agustín (2018). La moral en la interpretación del pasado en la historiografía latina. Anuario de la Escuela de Historia Virtual, 14, 5-25. 